\title{
Effect of Long Term Application of Fertilizer and Manure on Establish Relationship between Soil Organic Carbon Fractions with Yield of Maize and Wheat Crops under Maize-Wheat Sequence in Heplustepts
}

\author{
S.C. Meena ${ }^{1 *}$, D.P. Singh ${ }^{1}$ and S.R. Meena ${ }^{2}$ \\ ${ }^{1}$ Department of Agri. Chem. \& Soil Science, Rajasthan College of Agriculture, \\ MPUAT, Udaipur, Rajasthan, India \\ ${ }^{2}$ Department of Agri., Pratapnagar, Udaipur, Rajasthan, India \\ *Corresponding author
}

\section{Keywords \\ Fertilizers, Organic manure, Organic carbon, Correlation, Regression. \\ Article Info \\ Accepted: \\ 04 July 2017 \\ Available Online: \\ 10 September 2017}

A B S T R A C T

A field study entitled "Effect of long term application of fertilizer and manure on Establish Relationship Between soil Organic Carbon Fractions with yield of maize and wheat crops under maize-wheat sequence in Heplustepts" was conducted during Kharif 2013-14 and 2014-15 in the Long Term Fertilizer Experiments initiated in Kharif, 1997 at the Instructional Farm of the Rajasthan College of Agriculture, Udaipur. The soil of the experimental site was sandy clay loam in texture, slightly alkaline in reaction, medium in available nitrogen and phosphorus, while high in potassium and zinc. The treatment consisted of control, $100 \%$ N, $100 \%$ NP, $100 \%$ NPK, $100 \%$ NPK + Zn, $100 \%$ NPK + $\mathrm{S}, 100 \% \mathrm{NPK}+\mathrm{Zn}+\mathrm{S}, 150 \% \mathrm{NPK}, 100 \% \mathrm{NPK}+$ Azotobacter, FYM $10 \mathrm{t} \mathrm{ha}^{-1}+100 \%$ NPK (-NPK of FYM), $100 \%$ NPK + FYM $10 \mathrm{tha}^{-1}$ and FYM $20 \mathrm{tha}^{-1}$. The application of farm yard manure also increased the passive and active soil organic carbon like humin, humic acid, fulvic acid, soil microbial carbon, water soluble carbon, water soluble carbohydrate and carbon mineralization. The significant positive correlation was found of organic carbon fraction with yield of maize and wheat crops. The regression of maize grain and stover yield, wheat grain and straw yield with its forms explains the variation in forms up to $92 \%, 99 \%, 99 \%$ and $98 \%$, respectively.

\section{Introduction}

Sustainable agriculture involves successful management of resources for increase agricultural production to satisfy changing human needs, while maintaining or enhancing the environment and natural resources (FAO, 1989). Long-term experiments initiated during 1930's and 1940's in India revealed that for sustained crop production adequate $\mathrm{P}$ and $\mathrm{K}$ fertilization was necessary along with nitrogen (Nambiar and Abrol, 1989). Many of' these experiments were not followed for detailed monitoring of soil fertility. Phosphorus is the second major nutrient in practical agriculture, being fairly immobile, becomes unavailable for plant uptake through conversion to insoluble form. Under such circumstances, microbial biomass although relatively small, can be an important source of $\mathrm{P}$ for microorganisms. Measurement of $\mathrm{P}$ content of soil biomass is essential for an accurate assessment of its important in $\mathrm{P}$ cycling crop nutrition (Rao and Khera 1995). 
The role of microorganisms in $\mathrm{P}$ turnover and $P$ availability was found to be more important in the organic system (Fliessbach et al., 1998). Microbial biomass phosphorus is a significant source of $\mathrm{P}$ to plants and its agricultural effectiveness could be modified by the addition of limestone. Fertilizers and organic amendments i.e., the application of $\mathrm{N}$, $\mathrm{P}, \mathrm{K}$ and FYM increasing of soil microbialbiomass $\mathrm{C}$ and dehydrogenase activity (He et al., 1998). The mineral-fertilizer recommendations are inadequate, whereas annual application of FYM along with NPK fertilizers sustains yield and soil productivity (Ranjan Bhattacharyya et al., 2008). The application of chemical fertilizer along with organic manure increased soil fertility status in terms of $\mathrm{pH}$, organic carbon, available $\mathrm{N}$, $\mathrm{P}, \mathrm{K}, \mathrm{S}$ and $\mathrm{B}$ as compared to its initial values of cropping system (Manjhi et al., 2014). The major constraint affecting the soil fertility is the adequate availability of suitable fertilizer and organic manures. It's very difficult task to predict about its fertility make-up. As the soil fertility is decreasing day by day due to low use of farmyard manure and consequently increase in use of chemical fertilizers, our aim is to study the trend of soil status of soil in long run. The organic matter is decreasing in our soil. Therefore such study will generate useful information on managing soil health.

\section{Materials and Methods}

At the inception of the experiment, the composite soil samples were drawn from 0-15 $\mathrm{cm}$ depth prior to treatment application in order to as certain initial fertility status and physico-chemical properties of the experimental soil. The experiment was carried out at the Instructional Farm of the Rajasthan College of Agriculture, Udaipur, in randomized block design (RBD) with four replications The treatment consisted of three sources chemical fertilizers, organic manure and bio-fertilizer (Azotobacter) and their combinations, viz., control, $100 \% \mathrm{~N}, 100 \%$
NP, $100 \%$ NPK, $100 \%$ NPK + Zn, $100 \%$ $\mathrm{NPK}+\mathrm{S}, 100 \% \mathrm{NPK}+\mathrm{Zn}+\mathrm{S}, 150 \% \mathrm{NPK}$, $100 \%$ NPK + Azotobacter, FYM $10 \mathrm{t} \mathrm{ha}^{-1}+$ $100 \%$ NPK (-NPK of FYM), $100 \%$ NPK + FYM $10 \mathrm{t} \mathrm{ha}^{-1}$ and FYM $20 \mathrm{t} \mathrm{ha}^{-1}$. Statistical analysis was done as outlined by Panse and Sukhatme (1985). The data so generated during the course of present investigation were subjected to simple correlation, regression analysis (Steel and Torrie, 1980). Pooled analysis of the data for two year was carried out using standard analysis of variance suggested by Gomez and Gomez (1984).

\section{Results and Discussion}

The soil microbial biomass carbon fraction ascribed highly significant positive relationship only with wheat grain yield $(r=$ $\left.0.488^{* *}\right)$ and significantly positive relationship with maize grain yield $\left(\mathrm{r}=0.421^{*}\right)$, maize stover yield $(0.384 *)$ and wheat straw yield $(0.390 * *)$. The soil microbial biomass nitrogen fraction ascribed highly significant positive relationship with wheat grain yield $\left(\mathrm{r}=0.608^{*}\right)$, maize grain yield $(0.520 * *)$, maize stover yield $(0.491 * *)$ and wheat straw yield $\left(0.511^{* *}\right)$.

The SMBP fraction ascribed significant positive relationship with maize grain yield $\left(\mathrm{r}=0.430^{*}\right)$, maize stover yield $\left(0.331^{*}\right)$ and significant positive relationship with wheat grain yield $\left(\mathrm{r}=0.310^{*}\right)$. The water soluble carbon fraction ascribed significant positive relationship with maize grain yield $\left(\mathrm{r}=0.425^{*}\right)$, maize stover yield $\left(\mathrm{r}=0.424^{*}\right)$, wheat grain yield $\left(\mathrm{r}=0.426^{*}\right)$ and wheat straw yield $\left(0.336^{*}\right)$.

The water soluble carbohydrates fraction ascribed highly significant positive relationship with maize grain yield ( $r=$ $0.507 * *)$, maize stover yield, wheat grain yield $(\mathrm{r}=0.637 * *)$ and wheat straw yield $(\mathrm{r}=0.612 * *)$. The soil dehydrogenase activity fraction ascribed significant positive 
relationship with maize grain yield $\left(\mathrm{r}=0.360^{*}\right)$, maize stover yield $(\mathrm{r}=0.364 *)$ and wheat grain yield $(0.314 *)$. The carbon mineralization fraction ascribed highly significant positive relationship with maize grain yield $\left(0.557^{* *}\right)$. maize stover yield $\left(\mathrm{r}=0.636^{* *}\right)$, wheat grain yield $\left(\mathrm{r}=0.577^{* *}\right)$ and wheat straw yield $(\mathrm{r}=0.554 * *)$.

The humic acid fraction ascribed significant $\mathrm{p}$ ositive relationship with only wheat grain yield $\quad(\mathrm{r}=0.321 *), \quad$ In case of humic acid fraction non significant positive re lationship with maize grain yield, maize stover yield and wheat straw yield. The fulvic acid fraction ascribed all maize grain and stover yield and wheat grain and straw yield observed non-significant. The humin fraction ascribed highly significant positive relationship with maize grain yield $\left(\mathrm{r}=0.605^{* *}\right)$, maize stover yield $\left(\mathrm{r}=0.613^{* *}\right)$, wheat grain yield $(\mathrm{r}=0.632 * *)$ and wheat straw yield $(\mathrm{r}=0.600 * *)$.

The soil microbial biomass carbon highly significantly correlated with soil microbial biomass nitrogen $(\mathrm{r}=0.829 * *)$, water soluble carbon $\left(\mathrm{r}=0.776^{* *}\right)$, humic acid $(\mathrm{r}=0.727 * *)$, Humin $(\mathrm{r}=0.729 * *)$ and significant positive relationship with soil microbial biomass phosphorus $\left(\mathrm{r}=0.608^{*}\right)$ and fulvic acid $(\mathrm{r}=0.701 *)$.

The soil microbial biomass nitrogen highly significantly correlated with SMBP $(\mathrm{r}=0.813 * *), \quad$ DHA $\quad(\mathrm{r}=0.751 * *), \quad$ carbon mineralization $\left(\mathrm{r}=0.825^{* *}\right)$, humic acid $(\mathrm{r}=0.779 * *), \quad$ humin $\quad(\mathrm{r}=0.827 * *) \quad$ and significant positive relationship with water soluble carbohydrates $\left(\mathrm{r}=0.637^{*}\right)$ and fulvic acid $\left(\mathrm{r}=0.653^{*}\right)$. The soil microbial biomass phosphorus found highly significantly correlated with DHA $\left(\mathrm{r}=0.810^{* *}\right), \quad$ carbon mineralization $(\mathrm{r}=0.809 * *)$ and humin $(\mathrm{r}=0.739 * *)$. The water soluble carbon found highly significantly correlated with DHA $(\mathrm{r}=0.892 * *)$, humic acid $(\mathrm{r}=0.710 * *)$ and significant positive relationship with WSCO $\left(\mathrm{r}=0.631^{*}\right)$, carbon mineralization $\left(\mathrm{r}=0.619^{*}\right)$, fulvic acid $\left(\mathrm{r}=0.695^{*}\right)$ and humin $\left(\mathrm{r}=0.606^{*}\right)$.

The water soluble carbohydrate significantly correlated with DHA $\left(\mathrm{r}=0.594^{*}\right)$, carbon mineralization $\left(\mathrm{r}=0.633^{*}\right)$ and humin $\left(\mathrm{r}=0.666^{*}\right)$.

The soil dehydrogenase activity found highly significantly correlated with carbon mineralization $(\mathrm{r}=0.744 * *)$ and significant positive relationship with humic acid $(\mathrm{r}=0.631 *)$, fulvic acid $(\mathrm{r}=0.582 *)$ and humin $\left(\mathrm{r}=0.600^{*}\right)$. The carbon mineralization highly significantly correlated only with humin $(\mathrm{r}=0.893 * *)$ and significant positive relationship with humic acid $\left(\mathrm{r}=0.674^{*}\right)$.The humic acid highly significantly correlated with fulvic acid $(\mathrm{r}=0.952 * *)$ and humin $(\mathrm{r}=0.776 * *)$. The fulvic acid significant correlated with humin $(\mathrm{r}=0.634 *)$.

\section{Pooled stepwise regression}

The regression of maize grain and stover yield, wheat grain and straw yield with its forms explains the variation in forms up to $92 \%, 99 \%, 99 \%$ and $98 \%$ respectively. soil microbial biomass carbon followed by Soil microbial biomass nitrogen, soil microbial biomass phosphorus, water soluble carbon, water soluble carbohydrates, soil dehydrogenase activity, humic acid, fulvic acid and humin to the maximum extent. The soil microbial biomass carbon fraction ascribed highly significant positive relationship with wheat grain yield, maize grain yield, soil microbial biomass nitrogen, water soluble carbon, humic acid, Humin and significant positive relationship with soil microbial biomass phosphorus and fulvic acid. The results of present investigation are in line with the finding of Thakre and Ravankar (2004) and Santhy (1999). 
Table.1 Correlation co-efficient between different forms of active fraction and maize \& wheat yield of LTFE soils in 2013-14 and 2014-15

\begin{tabular}{|c|l|l|}
\hline \multirow{2}{*}{ Sr. no. } & \multicolumn{2}{|c|}{ Correlation between } \\
\cline { 2 - 4 } & \multicolumn{2}{|c|}{ Active pools forms to crop yield } \\
\hline 1 & Soil Microbial Biomass Carbon v/s Maize grain Yield & $0.421^{*}$ \\
\hline 2 & Soil Microbial Biomass Carbon v/s Maize stover Yield & $0.384^{*}$ \\
\hline 3 & Soil Microbial Biomass Carbon v/s Wheat Grain Yield & $0.488^{* *}$ \\
\hline 4 & Soil Microbial Biomass Carbon v/s Wheat Straw Yield & $0.390^{*}$ \\
\hline 5 & Soil Microbial Biomass Nitrogen v/s Maize grain Yield & $0.520^{* *}$ \\
\hline 6 & Soil Microbial Biomass Nitrogen v/s Maize stover Yield & $0.491^{* *}$ \\
\hline 7 & Soil Microbial Biomass Nitrogen v/s Wheat Grain Yield & $0.608^{* *}$ \\
\hline 8 & Soil Microbial Biomass Nitrogen v/s Wheat Straw Yield & $0.511^{* *}$ \\
\hline 9 & Soil Microbial Biomass Phosphorus v/s Maize grain Yield & $0.430^{*}$ \\
\hline 10 & Soil Microbial Biomass Phosphorus v/s Maize stover Yield & $0.331^{*}$ \\
\hline 11 & Soil Microbial Biomass Phosphorus v/s Wheat Grain Yield & $0.310^{*}$ \\
\hline 12 & Soil Microbial Biomass Phosphorus v/s Wheat Straw Yield & 0.294 \\
\hline 13 & Water Soluble Carbon v/s Maize grain Yield & $0.425^{*}$ \\
\hline 14 & Water Soluble Carbon v/s Maize stover Yield & $0.424^{*}$ \\
\hline 15 & Water Soluble Carbon v/s Wheat Grain Yield & $0.426^{*}$ \\
\hline 16 & Water Soluble Carbon v/s Wheat Straw Yield & $0.336^{*}$ \\
\hline 17 & Water Soluble Carbohydrates v/s Maize grain Yield & $0.507^{* *}$ \\
\hline 18 & Water Soluble Carbohydrates v/s Maize stover Yield & $0.471^{* *}$ \\
\hline 19 & Water Soluble Carbohydrates v/s Wheat Grain Yield & $0.637^{* *}$ \\
\hline 20 & Water Soluble Carbohydrates v/s Wheat Straw Yield & $0.612^{* *}$ \\
\hline 21 & Soil Dehydrogenous Activity v/s Maize grain Yield & $0.360^{*}$ \\
\hline 22 & Soil Dehydrogenous Activity v/s Maize stover Yield & $0.364^{*}$ \\
\hline 23 & Soil Dehydrogenous Activity v/s Wheat Grain Yield & $0.314^{*}$ \\
\hline 24 & Soil Dehydrogenous Activity v/s Wheat Straw Yield & 0.255 \\
\hline 25 & Carbon Mineralization v/s Maize grain Yield & $0.557^{* *}$ \\
\hline 26 & Carbon Mineralization v/s Maize stover Yield & $0.636^{* *}$ \\
\hline 27 & Carbon Mineralization v/s Wheat Grain Yield & $0.577^{* *}$ \\
\hline 28 & Carbon Mineralization v/s Wheat Straw Yield & $0.554^{* *}$ \\
\hline
\end{tabular}

Table. 2 Correlation co-efficient between different forms of passive fraction and maize \& wheat yield of LTFE soils in 2013-14 and 2014-15 year

\begin{tabular}{|c|l|l|}
\hline \multirow{2}{*}{$\begin{array}{l}\text { Sr. } \\
\text { no. }\end{array}$} & \multicolumn{1}{|c|}{ Correlation between } \\
\cline { 2 - 3 } & \multicolumn{1}{|c|}{ Passive pools forms to crop yield } \\
\hline 1 & Humic Acid v/s Maize grain Yield & 0.191 \\
\hline 2 & Humic Acid v/s Maize stover Yield & 0.273 \\
\hline 3 & Humic Acid v/s Wheat Grain Yield & $0.321^{*}$ \\
\hline 4 & Humic Acid v/s Wheat Straw Yield & 0.196 \\
\hline 5 & Fulvic Acidv/s Maize grain Yield & 0.088 \\
\hline 6 & Fulvic Acidv/s Maize stover Yield & 0.166 \\
\hline 7 & Fulvic Acidv/s Wheat Grain Yield & 0.201 \\
\hline 8 & Fulvic Acidv/s Wheat Straw Yield & 0.075 \\
\hline 9 & Humin v/s Maize grain Yield & $0.605^{* *}$ \\
\hline 10 & Humin v/s Maize stover Yield & $0.613^{* *}$ \\
\hline 11 & Humin v/s Wheat Grain Yield & $0.632^{* *}$ \\
\hline 12 & Huminv/s Wheat Straw Yield & $0.600^{* *}$ \\
\hline
\end{tabular}

* Significant, ** highly significant 
Table.3 Correlation coefficient between forms of active and passive pools fraction to among forms of LTFE soils in 2013-14 and 2014-15 year

\begin{tabular}{|c|c|c|c|c|c|}
\hline \multirow{2}{*}{$\begin{array}{l}\text { Sr. } \\
\text { no. }\end{array}$} & \multicolumn{2}{|c|}{$\begin{array}{c}\text { Correlation between } \\
\end{array}$} & \multirow{2}{*}{$\begin{array}{l}\text { Sr. } \\
\text { no. }\end{array}$} & \multicolumn{2}{|c|}{ Correlation between } \\
\hline & Active to Among forn & sive Forms & & Active to Among form & assive Forms \\
\hline 1 & SMBC v/s SMBN & $0.829 * *$ & 24 & SMBP v/s HUMIN & $0.739 * *$ \\
\hline 2 & SMBC v/s SMBP & $0.608 *$ & 25 & WSC v/s WSCO & $0.631^{*}$ \\
\hline 3 & SMBC v/s WSC & $0.776 * *$ & 26 & WSC v/s DHA & $0.892 * *$ \\
\hline 4 & SMBC v/s WSCO & 0.568 & 27 & WSC v/s CAR. MIN. & $0.619 *$ \\
\hline 5 & SMBC v/s DHA & 0.552 & 28 & WSC v/s H.A. & $0.710 * *$ \\
\hline 6 & SMBC v/s CAR. MIN. & 0.554 & 29 & WSC v/s F.A & $0.695 *$ \\
\hline 7 & SMBC v/s H.A. & $0.727 * *$ & 30 & WSC v/s HUMIN & $0.606^{*}$ \\
\hline 8 & SMBC v/s F.A. & $0.701 *$ & 31 & WSCO v/s DHA & $0.594 *$ \\
\hline 9 & SMBC v/s HUMIN & $0.729 * *$ & 32 & WSCO v/s CAR. MIN. & $0.633^{*}$ \\
\hline 10 & SMBN v/s SMBP & $0.813 * *$ & 33 & WSCO v/s H.A. & 0.498 \\
\hline 11 & SMBN v/s WSC & $0.790 * *$ & 34 & WSCO v/s F.A & 0.402 \\
\hline 12 & SMBN v/s WSCO & $0.637 *$ & 35 & WSCO v/s HUMIN & $0.666^{*}$ \\
\hline 13 & SMBN v/s DHA & $0.751 * *$ & 36 & DHA v/s CAR.MIN. & $0.744 * *$ \\
\hline 14 & SMBN v/s CAR. MIN. & $0.825 * *$ & 37 & DHA v/s H.A. & $0.631 *$ \\
\hline 15 & SMBN v/s H.A. & $0.779 * *$ & 38 & DHA v/s F.A & $0.582 *$ \\
\hline 16 & SMBN v/s F.A. & $0.653 *$ & 39 & DHA v/s HUMIN & $0.600^{*}$ \\
\hline 17 & SMBN v/s HUMIN & $0.827 * *$ & 40 & CAR.MIN. v/s H.A. & $0.674 *$ \\
\hline 18 & SMBP v/s WSC & $0.695^{*}$ & 41 & CAR.MIN. v/s F.A & 0.494 \\
\hline 19 & SMBP v/s WSCO & 0.456 & 42 & CAR.MIN. v/s HUMIN & $0.893 * *$ \\
\hline 20 & SMBP v/s DHA & $0.810 * *$ & 43 & H.A. v/s F.A & $0.952 * *$ \\
\hline 21 & SMBP v/s CAR.MIN. & $0.809 * *$ & 44 & H.A. v/s HUMIN & $0.776^{* *}$ \\
\hline 22 & SMBP v/s H.A. & 0.541 & 45 & F.A. v/s HUMIN & $0.634 *$ \\
\hline 23 & SMBP v/s F.A. & 0.407 & & & \\
\hline
\end{tabular}

* Significant, ** highly significant

Table.4 Regression equation between crop yield to active and passive forms in LTFE

\begin{tabular}{|c|c|c|}
\hline $\begin{array}{c}\text { Dependent } \\
\text { variables }\end{array}$ & Regression equation & $\mathbf{R}^{2}$ \\
\hline MGY & $\begin{array}{c}\mathrm{Y}=-1027-0.787(\mathrm{SMBC})+34.83(\mathrm{SMBN})-34.44(\mathrm{SMBP})+8.96(\mathrm{WSC}) \\
-4.35(\mathrm{WSCO})-0.10(\mathrm{DHA})-5.15(\mathrm{CAR} . \mathrm{MIN})-3.03(\mathrm{HA})+0.89(\mathrm{FA})+ \\
80.46(\mathrm{HUMIN})\end{array}$ & 0.926 \\
\hline MSY & $\begin{array}{c}\mathrm{Y}=2270-1.15(\mathrm{SMBC})+53.51(\mathrm{SMBN})-111.99(\mathrm{SMBP})+22.33(\mathrm{WSC}) \\
-13.69(\mathrm{WSCO})-0.823(\mathrm{DHA})+11.17(\mathrm{CAR} . \mathrm{MIN})-6.125(\mathrm{HA})+ \\
1.159(\mathrm{FA})+144.8(\mathrm{HUMIN})\end{array}$ & 0.996 \\
\hline WGY & $\begin{array}{c}\mathrm{Y}=2403-4.378(\mathrm{SMBC})+299.4(\mathrm{SMBN})-298.5(\mathrm{SMBP})+43.82(\mathrm{WSC}) \\
-16.15(\mathrm{WSCO})+0.423(\mathrm{DHA})-22.59(\mathrm{CAR} . \mathrm{MIN})-14.29(\mathrm{HA})- \\
3.556(\mathrm{FA})+418.7(\mathrm{HUMIN})\end{array}$ & 0.984 \\
\hline WSY & $\begin{array}{c}\mathrm{Y}=2374-6.630(\mathrm{SMBC})+332.2(\mathrm{SMBN})-308.8(\mathrm{SMBP})+ \\
65.64(\mathrm{WSC})-13.61(\mathrm{WSCO})-21.83(\mathrm{DHA})-11.04(\mathrm{CAR} . \mathrm{MIN})- \\
25.13(\mathrm{HA})+17.59(\mathrm{FA})+534.7(\mathrm{HUMIN})\end{array}$ & 0.978 \\
\hline
\end{tabular}


The soil microbial biomass nitrogen fraction ascribed highly significant positive relationship with wheat grain yield, wheat straw yield, maize grain yield, soil microbial biomass phosphorus, dehydrogenase activity, carbon mineralization, humic acid, humin and significant positive relationship with water soluble carbohydrates and fulvic acid. These observations are in close conformity to those obtained by Vance et al., (1987).

The soil microbial biomass phosphorus fraction ascribed highly significant positive relationship with maize grain yield and significant positive relationship with wheat grain yield, dehydrogenase activity, carbon mineralization and humin.

The water soluble carbon fraction ascribed significant positive relationship with maize grain yield, maize stover yield and wheat grain yield. The water soluble carbon highly significantly correlated with dehydrogenase activity and humic acid, while it shows significant positive relationship with WSCO, carbon mineralization, fulvic acid and humin. The Water Soluble Carbohydrates fraction ascribed highly significant positive relationship with maize grain yield, wheat grain yield, wheat straw yield. The water soluble carbohydrate significantly correlated with dehydrogenase activity, carbon mineralization and humin. The dehydrogenase activity fraction ascribed significant positive relationship with maize grain yield, maize stover yield, carbon mineralization and significant positive relationship with humic acid, fulvic acid and humin (Tables 1-4).

The carbon mineralization fraction ascribed highly significant positive relationship with maize stover yield, wheat grain yield, humin and significant positive relationship with maize grain yield, wheat straw yield and humic acid. Verma and Mathur (2007) show relationship among active pools of soil organic matter and $\mathrm{C} / \mathrm{N}, \mathrm{SMBC}, \mathrm{SMBN}$, SMBP. The $\mathrm{C} / \mathrm{N}$ ratio was highly and significantly correlated with soil microbial biomass carbon (SMBC), soil microbial biomass nitrogen (SMBN), water soluble carbon (WSC), water soluble carbohydrates (WS-CHO)and dehydrogenase activity (DHA) under maize crop. The humic acid fraction ascribed highly significant positive relationship with maize grain and stover yield and wheat straw yield, fulvic acid and humin and significant positive relationship with wheat grain yield. The fulvic acid fraction maize grain and stover yield, wheat grain and straw yield observed non-significant. The fulvic acid significant correlated with humin. The humin fraction ascribed highly significant positive relationship with maize grain and stover yield, wheat grain yield and straw yield.

\section{References}

Brookes, P.C, Powlson, D.S. and Jenkinson, D.S. 1982.Measurement of microbial biomass phosphorus in soils. Soil Biology and Biochemistry, 14: 319-321.

Brookes, P.C., Landman, A., Pruden, G. and Jenkinson, D.S. 1985. Chloroform fumigation and release of soil "Nh a rapid direct extraction method to measure microbial biomass $\mathrm{N}$ in soil. Soil Biology and Biochemistry, 17: 837842.

FAO, 1989. Sustainable development and natural resource management. Food and Agriculture Organization of the United Nations, Rome, FAO Agriculture series, No. 22, Chapter 3, pp. 84-90.

Filon, L.I., and Shelar, L.A. 2002. Effect of agricultural use and long term application of fertilizer on humus status of dark grey forest soils. Agrikhimiya, Pp. 16-21.

Fliessbach, A., Mader, P. and Dubois, D. 
1998. DOC Long-Term Field Experiment: Soil Fertility in Organic Farming Systems, ed. ISSS, World Congress of Soil Science, Montpellier. Technical Series No.58.

Ghoshal, N., and Singh, K.P. 1995. Effects of farmyard manure and inorganic fertilizer on the dynamics of soil microbial biomass in a tropical dry land agro ecosystem. Biology and fertility of Soils, 19: 231-238.

Gomez, K.A., and Gomez, A.A. 1984. Statistical Procedure for Agricultural Research, John Willey and Sons, New York.

Nambiar, K.K.M., and Abrol, I.P. 1989. Long term fertilizer experiment in India- An overview. Fertilizer News, 38 (8): 11-
20.

Panse, V.G., and Sukhatme, P.V. 1985. Statist ical Methods for Agricultu-ral workers. Publication and Information Division ICAR, New Delhi.

Thakre, S.K., and Ravankar, H.N. 2004. Long term effect of fertilization on fractionation of organic matter and their correlation with soil properties and yield of sorghum. Journal of Soils and Crops, 14: 354-357.

Tianu, M., 1997. Influence of the difference technological manures used in long term experiments on the evolution of soil organic matter. Analeleinstitului de Cercetaripentru Cerealesi Plante Technice, pundulea, 63: 105-110.

\section{How to cite this article:}

Meena, S.C., D.P. Singh and Meena, S.R. 2017. Effect of Long Term Application of Fertilizer and Manure on Establish Relationship between Soil Organic Carbon Fractions with Yield of Maize and Wheat Cropsunder Maize-Wheat Sequence in Heplustepts. Int.J.Curr.Microbiol.App.Sci. 6(9): 600-606. doi: https://doi.org/10.20546/ijcmas.2017.609.073 